\title{
Studies on Arthrospore of Trichophyton rubrum (I)
}

\author{
Makoto MIYAZI* and Kazuko NISHIMURA** \\ * Department of Dermatology of Narashino National Hospital. Department of Sanitary \\ Bacteriology of Institute of Food Microbiology, Chiba University. \\ **Department of Dermatology, Chiba University School of Medicine.
}

It was often noted that hyphae of Trichophyton rubrum that caused the superficial infections formed arthrospores. But only a few authors observed the separation of the individual arthrospores from hyphae in horny layer or hair follicle, subsequent acquisition of a spherical shape, ${ }^{1 / 2) 3}$ ) and the germination of the spherical cells ${ }^{3)}$

In 1959, Rippon and Scherr ${ }^{4}$ cultivated Trichophyton rubrum, Microsporum Audoduini, and Cladosporium mansonii on cysteine-gradient plates and could induce a morphological change similar to the dimorphism in these strains whereby yeastlike "spherules" were formed. Further, they") observed that these spherical cells had the ability to invade the deep tissues when injected into mice.

This paper is concerned with the formation, pathogenicity and germination of these spherical cells.

\section{Materials and Methods}

Strains: Fifteen strains of Trichophyton rubrum from patients of dermatomycosis were employed in this study. Stock cultures were maintained on Sabouraud glucose agar at room temperature.

Media: Sabouraud glucose agar and brain heart infusion supplemented with $1 \%$ glucose (this was termed brain heart infusion glucose liquid medium) were employed. The $\mathrm{pH}$ was adjusted to 7.4 with $1 \mathrm{~N} \mathrm{NaOH}$.

Cultures and preparation of inocula: Brain heart infusion glucose liquid medium was delivered in $100 \mathrm{ml}$ quantities into Sakaguchi flasks and autoclaved at $121^{\circ} \mathrm{C}$ for $15 \mathrm{~min}$. The sterilized medium was inoculated with $1 \mathrm{ml}$ of the suspension of the spherical cells which contained $10 \mathrm{mg}$ wet weight of the cells from shaking culture. The liquid cultures were incubated on a reciprocating shaker at $37^{\circ} \mathrm{C}$ for two weeks. Growth was measured according to the following procedure. Each flask was vigorously shaken and the contents were filtered through five layers of cotton gauze. The filtrate consisted of many spherical cells and a few short cellular chains (these two forms were termed spherical cells). Spherical cells of 7 day-cultures were employed for inoculation. As a control, the following culture was taken. Sabouraud glucose agar was delivered in $100 \mathrm{ml}$ quantities into $300 \mathrm{ml}$ flasks and sterilized. This medium was inoculated with Trichophyton rubrum and incubated at $27^{\circ} \mathrm{C}$ for 20 days. To each flask, $10 \mathrm{ml}$ of sterile saline solution was added and vigorously shaken. Then the suspension was centrifuged and the mixture of short filaments, microconidia and a few macroconidia was separated (these were termed hyphae). Both spherical cells and hyphae were resuspended separately in sterile saline solution, and mice were injected with one of the two suspensions intraperitoneally.

Animals and inoculation: Male mice of dd line weighing $22 \pm 1 \mathrm{~g}$ were used. They were divided into four groups of three mice each. Two groups of mice were inoculated with 0.2 $\mathrm{ml}$ of the suspension of the spherical cells $(1 \mathrm{mg}$ or $10 \mathrm{mg}$ ) and the other two groups were injected with $0.2 \mathrm{ml}$ of the hyphae suspension (1 $\mathrm{mg}$ or $10 \mathrm{mg})$.

Autopsy: Groups of mice were usually dissected at 6 and 17 days after inoculation and examined grossly and microscopically. Sections were stained with hematoxylin-eosin and periodic acid-Schiff stain of Hotchkiss-McManus.

\section{Results}

Formation of spherical cells: After 3 days incubation of Trichophyton rubrum No-6, which 
was isolated from a patient suffering from tinea barbae, under continuous agitation in Sakaguchi flask, a few small filamentous pellets appeared. At this time hyphae were divided by septa at long intervals (about $10 \mu$ ). The width of hyphae was about $2 \mu$. After 6 days, interval of septa markedly shortened ( 3 to $5 \mu$ ) and the width of hyphae increased. After 7 days, segments of hyphae walled off, increased in volume, and acquired a spherical shape (about $5 \mu$ in diameter). These spherical cells originated from arthrospore formation but not from budding. After 8 days, the cells were swollen (about $7 \mu$ in diameter) and had thick cell

Table 1. Growth of Trichophyton Rubrum No. 6

\begin{tabular}{ccc}
\hline days & filamentous pellets & spherical cells \\
\hline 1 & $0.00 * \mathrm{~g}$ & $0.00 \mathrm{~g}$ \\
2 & 0.00 & 0.00 \\
3 & 0.28 & 0.00 \\
4 & 0.55 & 0.00 \\
5 & 1.00 & 0.00 \\
6 & 1.25 & 0.75 \\
7 & 1.40 & 1.95 \\
8 & 1.40 & 3.50 \\
9 & 1.35 & 4.25 \\
10 & 1.30 & 5.10 \\
11 & 1.40 & 5.30 \\
12 & 1.45 & 5.60 \\
13 & 1.40 & 5.65 \\
14 & 1.45 & 5.45
\end{tabular}

*wet weight
Table 3. Formation of spherical cells of Trichophyton rubrum

\begin{tabular}{ccccc}
\hline & \multicolumn{2}{c}{$37^{\circ} \mathrm{C}$} & \multicolumn{2}{c}{$25^{\circ} \mathrm{C}$} \\
\cline { 2 - 4 } $\begin{array}{c}\text { filamen- } \\
\text { tous } \\
\text { strains }\end{array}$ & $\begin{array}{c}\text { spherical } \\
\text { cells }\end{array}$ & $\begin{array}{c}\text { filamen- } \\
\text { tous } \\
\text { pellets }\end{array}$ & $\begin{array}{c}\text { spherical } \\
\text { cells }\end{array}$ \\
\hline 1 & +++ & - & + & - \\
2 & ++ & - & +++ & - \\
3 & ++ & - & +++ & - \\
4 & + & - & + & - \\
5 & +++ & +++ & + & - \\
6 & +++ & +++ & +++ & - \\
7 & +++ & + & +++ & - \\
8 & +++ & + & ++ & - \\
9 & +++ & +++ & ++ & - \\
10 & +++ & +++ & +++ & - \\
11 & +++ & - & +++ & - \\
12 & + & - & +++ & - \\
13 & +++ & - & +++ & - \\
14 & +++ & +++ & ++ & - \\
15 & +++ & - & ++ & - \\
\hline & & + & +
\end{tabular}

walls. Cytoplasm was stained deeply with a lactophenol cotton blue. After 10 days, these cells further increased in volume (about $10 \mu$ in diameter) and eventually burst. Figures 4, 5 and Tables 1, 2 summarized the results obtained. By this method, many uniform spherical cells were obtained. This phenomenon did not occur at $25^{\circ} \mathrm{C}$. Five out of 15 strains examined formed spherical cells abundantly under

Table 2. Relationship of $\mathrm{pH}$ to formation of spherical cells

$\begin{array}{ccccccccc}\mathrm{pH} & 5.0 & 6.0 & 6.5 & 7.0 & 7.4 & 8.0 & 9.0 & 10.0 \\ \text { spherical cells } & - & ++ & +++ & +++ & +++ & ++ & + & - \\ - & \begin{array}{c}+++ \\ \text { none }\end{array} & & & & & & \end{array}$

Fig. 4.

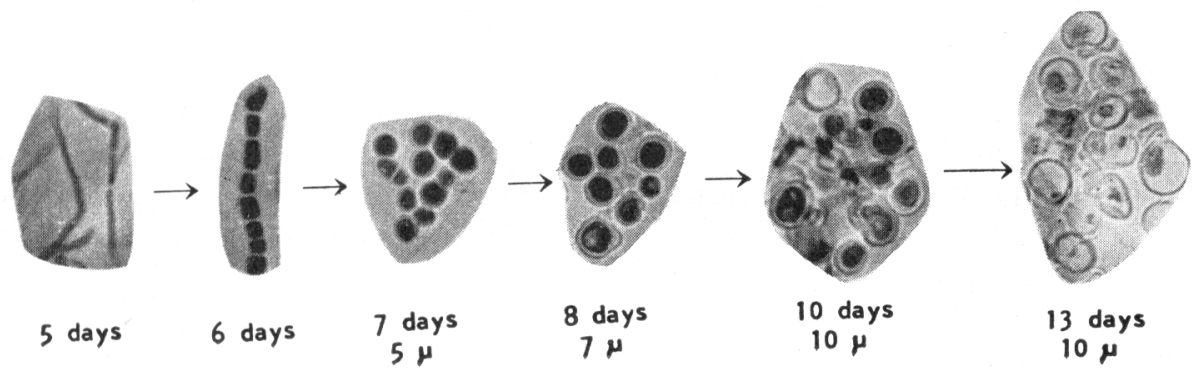


Fig. 5. Growth of Trichophyton rubrum No. 6

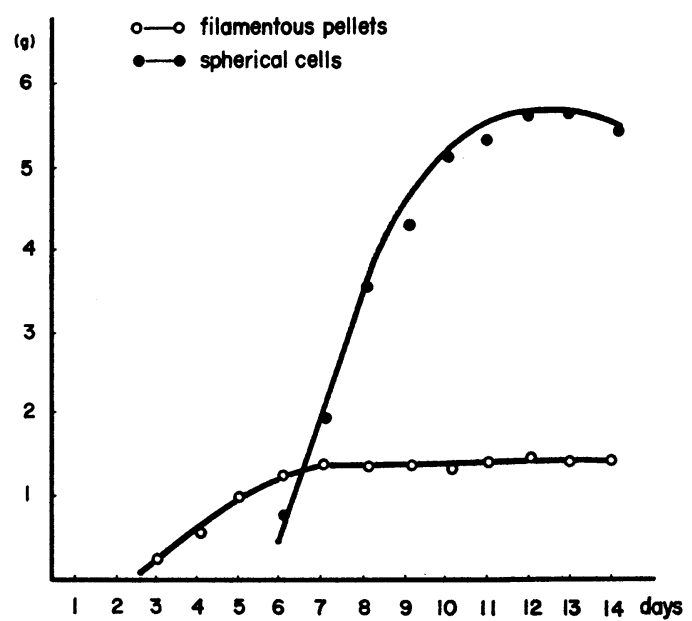

the above condition (Table 3). In both brain heart infusion liquid medium and Sabouraud liquid medium these spherical cells could germinate at $37^{\circ} \mathrm{C}$ at 6 hours after inoculation but not at $27^{\circ} \mathrm{C}$ (Figure 6).

Pathogenicity for mice: Pathogenicity of the spherical cells for mice was much greater than that of the hyphae (Table 4). Macroscopically, in mice inoculated spherical cells at 6 days after inoculation, the liver, spleen, diaphragm and abdominal wall (the site of injection) contained lesions of the mycotic-granuloma type. At 17 days after inoculation, the same findings were observed. On the other hand, when the hyphae were inoculated, the numbers of nodules were less than those with spherical cells.

Microscopically, nodules (inoculated spherical cells) were encapsulated and consisted of central zones of necrosis surrounded by cellular infiltrates which composed mainly of polymorphonuclear leukocytes when stained with hematoxylin and eosin. In the Hotchkiss-McManus stain, at 6 days after inoculation the spherical cells were usually located in the central zone of necrosis (Figure 7). Individual spherical cell swelled, estimated to be 5 to $7.5 \mu$ in diameter, and a few of them germinated (Figure 8). Seventeen days after inoculation these cells became larger (about $10 \mu$ in diameter) and more cells germinated (Figure 9). These spherical
Table 4. Autopsy

\begin{tabular}{|c|c|c|c|c|}
\hline & $\begin{array}{l}\text { spher- } \\
\text { ical cells } \\
1 \mathrm{mg}\end{array}$ & $\begin{array}{l}\text { hyphac } \\
1 \mathrm{mg}\end{array}$ & $\begin{array}{l}\text { spher- } \\
\text { ical } \\
\text { cells } \\
10 \mathrm{mg}\end{array}$ & $\begin{array}{l}\text { hyphae } \\
10 \mathrm{mg}\end{array}$ \\
\hline $\begin{array}{l}\text { abdominal wall } \\
\text { (the site of } \\
\text { injection) }\end{array}$ & $3 / 3^{*}$ & $1 / 3$ & $3 / 3$ & $3 / 3$ \\
\hline liver & $1 / 3$ & $1 / 3$ & $2 / 3$ & $3 / 3$ \\
\hline peritoneum & $2 / 3$ & $0 / 3$ & $2 / 3$ & $2 / 3$ \\
\hline diaphragm & $0 / 3$ & $1 / 3$ & $3 / 3$ & $0 / 3$ \\
\hline spleen & $1 / 3$ & $0 / 3$ & $2 / 3$ & $2 / 3$ \\
\hline kidney & $0 / 3$ & $0 / 3$ & $0 / 3$ & $0 / 3$ \\
\hline
\end{tabular}

*No. of mice which formed nodules/No. of mice injected.

cells and germ tubes in the sections were vividly stained with the Hotchkiss-McManus stain. Trichophyton rubrum could be recovered from the nodules which were dissected at 6 and 17 days. On the other hand, hyphae injected were destroyed in necrotic areas and although kept the figures, they were poorly stained with periodic acid-Schiff stain (Figure 10). Germination was never observed in the nodules and the fungus could be recovered from the lesions dissected at 6 days but not at 17 days.

\section{Discussion}

Only few authors have observed the whole sequence of the arthrospores of Trichophyton rubrum in horny layer or hair follicle; the formation of the spores, ripening into large spherical cells, ${ }^{1) 2}$ and the germination of the cells. ${ }^{3}$ )

A case that we experienced is shown in Figures 1, 2 and 3 . As shown in these Figures, hyphae which invaded in hair follicle were divided by septa at intervals of about $3.8 \mu$ and individual arthrospore detached from hyphae. These cells swelled and acquired a spherical shape (from 2.5 to $7.5 \mu$ in diameter). One of these spherical cells clearly germinated. Rippon and Scherr ${ }^{4)}$ cultured Trichophyton rubrum, Microsporum Audoduini, and Cladosporium mansonii on cysteinegraient plates and incubated suspensions of the strains in dialysis bags within the peritoneal cavity of rabbits and they obtained spherical cells. Further, they ${ }^{4}$ observed that these cells had the ability to invade the deep tissues when injected into experimental animals. Sternberg et al. ${ }^{5)}$ 


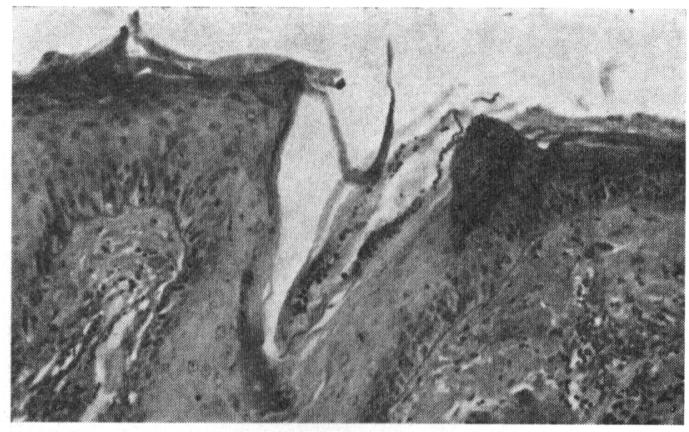

Fig. 1. PAS stain. $\times 100$

Hyphae invaded in the follicle.

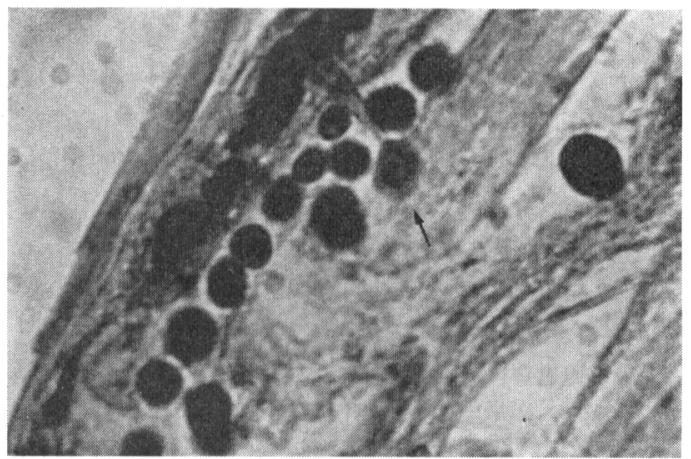

Fig. 3. PAS stain. $\times 1000$

Individual arthrospores detached from hyphae swelled and acquired spherical cells (from 2.5 to $7.5 \mu$ in diameter). One of them germinated.

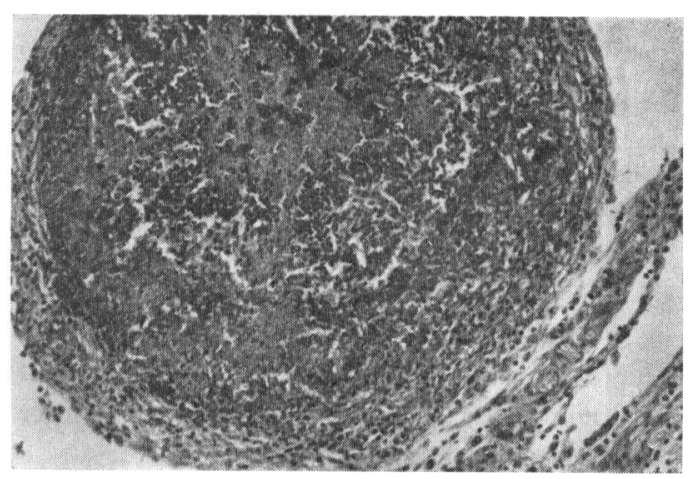

Fig. 7. PAS stain. $\times 100$

6 days after inoculation. The spherical cells were located in the central zone of necrosis.

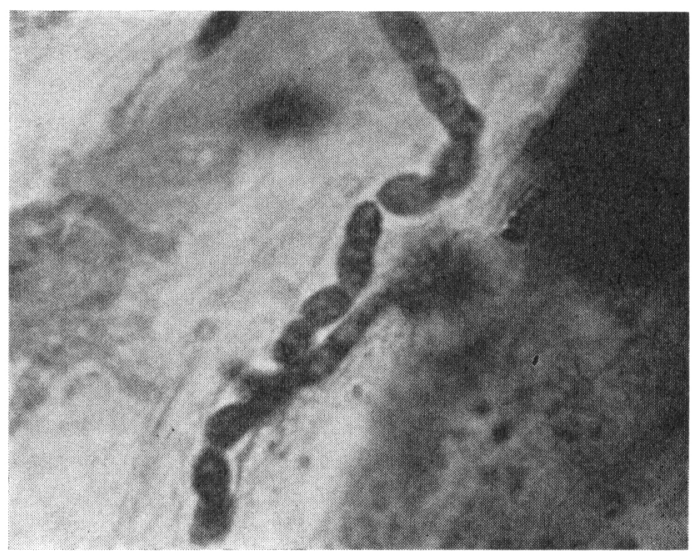

Fig. 2. PAS stain ${ }^{*} \times 1000$

Hyphae which invaded in hair follicle were divided by septa at intervals of about $3.8 \mu$.

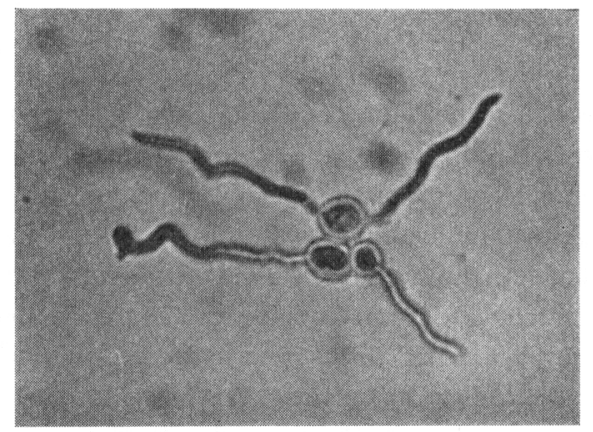

Fig. 6. Lactophenol cotton blue. $\times 400$ 6 hours after inoculation. Germination of spherical cells.

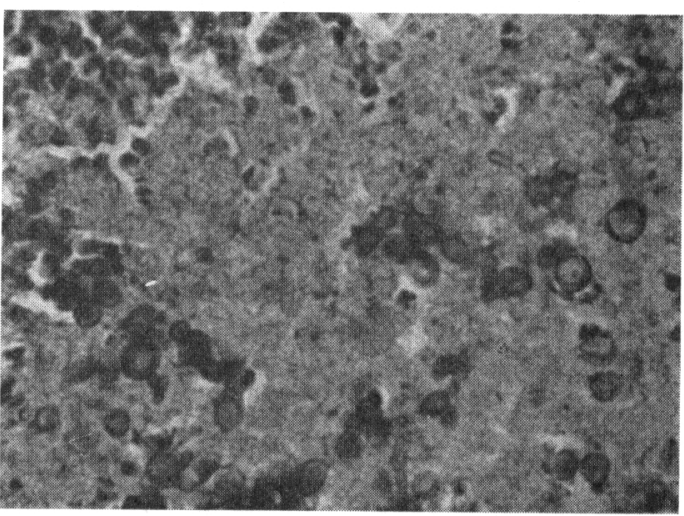

Fig. 8. PAS stain. $\times 400$

6 days after inoculation. Individual spherical cells swelled, 5 to $7.5 \mu$ in diameter, and some of them germinated. 


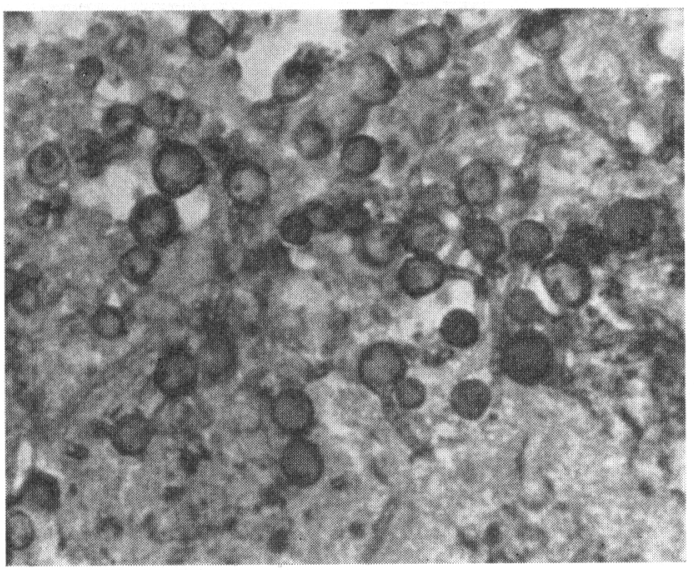

Fig. 9. PAS stain. $\times 400$

17 days after inoculation. Spherical cells became larger (about $10 \mu$ in diameter), and some of them germinated.

injected suspension of Trichophyton rubrum into mice and observed granulomatous masses on the liver, spleen and omentum in a few mice, and an occasional unicellular "spherule". They ${ }^{5)}$ indicated that the hyphae of Trichophyton rubrum had a tendency to form a spherical shape in deep tissues, and that these spherical cells enhanced greater ability to invade the deep organs of experimental animals than the hyphae. Rippon and Scherr ${ }^{4}$ also stated that HotchkissMcManus stains of squash smears from the internal organs of animals injected the fungus showed masses of single celled, multiple-budding, spherule-like forms and bulbous, which constricted short hyphal elements in compact masses within the tissue. But, as was shown in this experiment, in Trichophyton rubrum "budding" does not occur; these yeast-like "spherules" originate from arthrospores. With Trichophyton rubrum No-6 the authors could obtained uniform spherical cells under agitation in brain heart infusion glucose liquid medium at $37^{\circ} \mathrm{C}$. However, not all strains of the fungus can form spherical cells under the same condition. In our results, 5 out of 15 strains employed formed the spherical cells abundantly. The uniform spherical cells, when inoculated into mice intraperitoneally, swelled in the nodules, and some of them germinated. These swollen cells in the

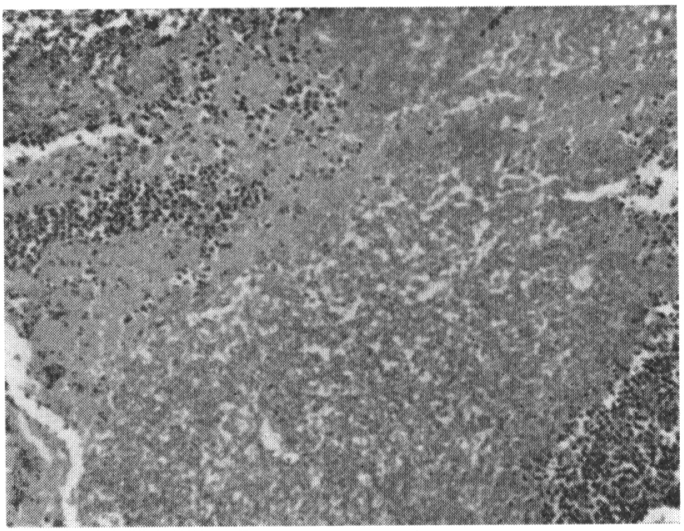

Fig. 10. PAS stain. $\times 100$

17 days after inoculation. Hydhae were destroyed in necrotic area.

nodules were clearly stained with periodic acidSchiff stain of Hotchkiss-McManus, and the fungus could be recovered from the lesions.

On the other hand, the forms of the hyphae in the nodules showed ghost-like shapes and could not be reisolated from specimens of 17 days after inoculation. Germination was never observed in the tissues.

\section{Summary}

1) Trichophyton rubrum No-6 formed spherical cells when cultured in brain heart infusion glucose liquid medium under continuous agitation at $37^{\circ} \mathrm{C}$.

2) Five out of 15 strains of Trichophyton rubrum could form the spherical cells under this condition.

3) Pathogenicity for mice of the spherical cells was much greater than that of hyphae.

4) The spherical cells inoculated into mice intraperitoneally swelled in the lesions, and some of the swollen cells germinated.

5) In both brain heart infusion liquid medium and Sabouraud liquid medium these spherical cells could germinate at $37^{\circ} \mathrm{C}$ at 6 hours after inoculation but not at $27^{\circ} \mathrm{C}$.

\section{REFERENCES}

1) Götz, H.: Mycopathol. et Mycol. Appl., 12, 124 (1959) 
2) Hanusòvá, S.: Arch. klin. exp. Derm., 217, 255 (1963)

3) Kobayashi, A.: Japan. J. Dermat. Ser. A, 78, 722, 1963 (in Japanese)

4) Rippon, J.W. and Scherr, G.H.: Mycologia,
51, 902 (1959)

5) Sternberg, T.H., Tarbet, H.E. Newcomer, V. D. and Winer, L.H.: Jour. Inv. Derm., 19, 373 (1952)

(Received for Publication, January, 25, 1971) 